\title{
EFFECTS OF NITROGEN RATES ON FODDER YIELDS IN CAULIFLOWER PRODUCTION $^{1}$
}

\author{
V. Bjelić, S. Vučković, Đ. Moravčević ${ }^{2}$
}

Abstract: The trials with cauliflower were performed with different nitrogen rates $(80,120$ and 160 $\mathrm{kg} \mathrm{ha}^{-1}$ ) under field conditions. Nitrogen was not applied in the control variant. The trials were carried out in soil of moderate fertility (brown forest soil). The nitrogen application increased the yield of fodder (stems and leaves) on the average by $26.20 \mathrm{tha}^{-1}$. The optimum nitrogen rate was $120 \mathrm{~kg} \mathrm{ha}^{-1}$.

Key words: cauliflower, nitrogen, fodder, yield.

\section{Introduction}

Cauliflower is an important vegetable grown for its tasty and nutritive heads (curds). After harvest of heads, stems and leaves remain in the field and are usually ploughed down and used as green manure. However, it would be much more useful if such a material is used as animal feed. Its chemical content is as follows: carbon hydrates $(2.7-4.3 \%)$, proteins $(0.91-1.7 \%)$, plant oils $(0.08-0.15 \%)$, cellulose $(0.8-1.5 \%)$, mineral matters $(0.6-1.3 \%)$, etc. Cauliflower usually contains vitamin C $(34 \mathrm{mg} \%)$, vitamin B1 $(0.06 \mathrm{mg} \%)$ and carotene $(0,06 \mathrm{mg} \%)$. It is also a source of mineral matters such as potassium, calcium and sulphur (Makarevič, 1998).

Stem and leaves constitute $65-72 \%$ of the total plant mass and animals (livestock and poultry) willingly eat them in the fresh (newly picked), dry or silage form. If animals are fed with greater amounts of the vegetable, milk and meat can have cauliflower-(cabbage)-like odour, and bloat can occur in livestock.

Many factors, including fertilising, affect the cauliflower production. In the processes of fertilising, different biogenic elements, especially nitrogen, phosphorus and potassium, are incorporated into the soil Nitrogen is a main creator of the yield, and its absorption by cauliflower is great $\left(130-240 \mathrm{~kg} \mathrm{ha}^{-1}\right)$. Furthermore, nitrogen is a constitutive element and it is an important constituent of many compounds (amino acids, proteins, chlorophyll). If nitrogen nutrition is insufficient, the development of cauliflower plants is slow, the number and size of leaves are lower, etc. On the other hand, excessive nitrogen nutrition has adverse effects - crop luxuriance increases very much, the relation between yields of curds and the vegetative mass (stem and leaves) impairs, production quality deteriorates, disease resistance weakens, etc.

Many authors have studied effects of nitrogen (fertilising) on cauliflower. Alt et al. (2000) established that fertilising with increasing rates of nitrogen $\left(100,150,200\right.$ and $\left.250 \mathrm{~kg} \mathrm{ha}^{-1}\right)$ increased cauliflower luxuriance, but the increase of the yield was not proportional (adequate). Due to it, the average participation of stem and leaves (fodder) in the total yield amounted up to $71 \%\left(240 \mathrm{~kg} \mathrm{ha}^{-1}\right)$. Vasjanovic (1985) points out to the nitrogen to phosphorus ratio in cauliflower nutrition and recommends the ratio of 1:0.6-0.8 in fertilising. Moreover, the amounts of $120-160 \mathrm{~kg} \mathrm{ha}^{-1}$, i.e. $80-120 \mathrm{~kg} \mathrm{ha}^{-1}$ of nitrogen, i.e. phosphorus, respectively, are recommended. Livingston et al. (1982) established that nitrogen, phosphorus, i.e. potassium increased the cauliflower yield by $57.6 \%, 30.1 \%$, i.e. $12.3 \%$, respectively. These authors applied 100 and $150 \mathrm{~kg}$ nitrogen $\mathrm{ha}^{-1}$ and $80 \mathrm{~kg}$ each of phosphorus and potassium ha ${ }^{-1}$. Everaarts (2000) indicated that approximately $100 \mathrm{~kg}$ nitrogen $\mathrm{ha}^{-1}$ was the optimum amount for cauliflower. production.

The objective of the present research is to contribute to studies on fertilising in the cauliflower

\section{Material and methods}

The two-year field trials with cauliflower (the Dutch variety Syria) were carried out on forest brown soil (eutric cambisol) in the vicinity of Belgrade (Radmilovac) in 1999 and 2000. The trial variants were as follows: $\mathrm{N}_{0} \mathrm{P}_{90} \mathrm{~K}_{80}$ (control), $\mathrm{N}_{80} \mathrm{P}_{90} \mathrm{~K}_{80}, \mathrm{~N}_{120} \mathrm{P}_{90} \mathrm{~K}_{80}$ and $\mathrm{N}_{160} \mathrm{P}_{90} \mathrm{~K}_{80}$. The nitrogen fertiliser KAN (27\% N) and NPK fertiliser (15:15:15) were applied.

1 Original scientific paper

$2 \mathrm{PhD}$ Vukašin Bjelić, Professor, PhD Savo Vučković, Professor, BsC Đorđe Moravčević, Assistant, Faculty of Agriculture, University of Belgrade, Belgrade-Zemun 
Transplants (seedlings) were grown in open beds. Five grams of seeds were sown per $\mathrm{m}^{2}$. Cauliflower was planted when it was 35 days old. The planting distance was $60 \times 50 \mathrm{~cm}$. Plants were regularly watered, hoed and protected against diseases and pests (insects).

The four-replicate trials were set up according to the randomised complete-block design. The plot size amounted to $9.6 \mathrm{~m}^{2}$ ( $\left.4 \times 2.4 \mathrm{~m}\right)$. Total of 32 plants were grown in each plot.

Harvest of cauliflower curds was done in October (two harvests). Harvested plants were pulled out and divided into stems and leaves, which were used to determine the fodder yield $\left(\mathrm{t} \mathrm{ha}^{-1}\right)$. Obtained results were processed by the analysis of variance.

Weather conditions

The year of 1999 had favourable conditions. First of all, there was sufficient amount of precipitation $(562 \mathrm{~mm})$. Only August was very dry. The temperatures were moderate and did not oscillate much.

Table 1. Mean monthly temperature and monthly sums precipitation during the period of investigation

\begin{tabular}{|l|c|c|c|c|}
\hline \multirow{2}{*}{ Months } & \multicolumn{2}{|c|}{ Temp. $\left({ }^{\circ} \mathrm{C}\right)$} & \multicolumn{2}{c|}{ Precipitation $(\mathrm{mm})$} \\
\cline { 2 - 5 } & 1999. & 2000. & 1999. & 2000. \\
\hline VI & 20.9 & 22.8 & 144 & 20 \\
\hline VII & 22.3 & 23.3 & 265 & 31 \\
\hline VIII & 23.0 & 25.7 & 12 & 7 \\
\hline IX & 20.5 & 18.6 & 85 & 72 \\
\hline X & 13.5 & 15.8 & 56 & 16 \\
\hline Average/Sum/prosek & 20.0 & 21.2 & 562 & 146 \\
\hline
\end{tabular}

The following year was characterised by warm and dry weather. The least favourable conditions for cauliflower were in August that was extremely hot and dry. Frequent and abundant irrigation of cauliflower was required.

\section{Results and discussion}

The average stem yield amounted to $11.85 \mathrm{t} \mathrm{ha}^{-1}$ (Table 2). Yields obtained in 1999 were higher, but only, by $1.14 \mathrm{t} \mathrm{ha}^{-1}$. Nitrogen increased stem yield by $5.36 \mathrm{t} \mathrm{ha}^{-1}$. This increase in 1999 was significantly higher (by $\left.6.95 \mathrm{t} \mathrm{ha}^{-1}\right)$ than the increase in $2000\left(3.76 \mathrm{t} \mathrm{ha}^{-1}\right)$. Greater amounts of nitrogen $\left(120\right.$ and $\left.160 \mathrm{t} \mathrm{ha}^{-1}\right)$ were more efficient, and their results were very even. Similar data were obtained by Csizinsky (1996) who applied 80-200 kg nitrogen $\mathrm{ha}^{-1}$ to the cauliflower crop. Kage et al. (2003) showed that each

Table 2. Stem yield

\begin{tabular}{|c|c|c|c|}
\hline \multirow{3}{*}{ VARIANT } & \multicolumn{2}{|c|}{ YIELD $\left(\mathrm{t} \mathrm{ha}^{-1}\right)$} & \multirow{3}{*}{ AVERAGE } \\
\hline & \multicolumn{2}{|c|}{ Years } & \\
\hline & 1999. & 2000. & \\
\hline 1. $\mathrm{N}_{0} \mathrm{P}_{90} \mathrm{~K}_{80}$ & 7.21 & 8.46 & 7.83 \\
\hline 2. $\quad \mathrm{N}_{80} \mathrm{P}_{90} \mathrm{~K}_{80}$ & 12.02 & 11.23 & 11.62 \\
\hline 3. $\quad \mathrm{N}_{120} \mathrm{P}_{90} \mathrm{~K}_{80}$ & 15.37 & 12.59 & 13.98 \\
\hline 4. $\quad \mathrm{N}_{160} \mathrm{P}_{90} \mathrm{~K}_{80}$ & 15.08 & 12.85 & 13.96 \\
\hline $\begin{array}{lc} & 1-4 \\
\text { AVERAGE } & 2-4 \\
\end{array}$ & $\begin{array}{l}12.42 \\
14.16\end{array}$ & $\begin{array}{l}11.28 \\
12.22 \\
\end{array}$ & $\begin{array}{l}11.85 \\
13.19 \\
\end{array}$ \\
\hline $\begin{array}{l}0.05 \\
0.01\end{array}$ & $\begin{array}{l}2.04 \\
2.94\end{array}$ & $\begin{array}{l}1.51 \\
2.17\end{array}$ & $\begin{array}{l}- \\
-\end{array}$ \\
\hline
\end{tabular}

increase of the nitrogen amount significantly increased the cauliflower (stem) yield. Their trial encompassed three nitrogen rates: 100, 150 and $200 \mathrm{t} \mathrm{ha}^{-1}$. According to Mangal et al. (1982) nitrogen did not affect the 
cauliflower yield. The reason for such results is that they studied the cauliflower production performed on a very fertile soil.

The leaf yield was rather high and amounted to $56.40 \mathrm{tha}^{-1}$ on the average (Table 3). Moreover, the leaf yield was higher by $3.36 \mathrm{t} \mathrm{ha}^{-1}$ in 1999 than in 2000. Nitrogen also increased this yield. The average increase amounted to $20.85 \mathrm{t} \mathrm{ha}^{-1}$. The output was significantly higher in 1999 in which the yield increase amounted even to $25.89 \mathrm{t} \mathrm{ha}^{-1}$. On the other hand, the yield increase in 2000 was $15.81 \mathrm{t} \mathrm{ha}^{-1}$. Leaves also strongly responded to greater nitrogen rates $\left(120\right.$ and $\left.160 \mathrm{~kg} \mathrm{ha}^{-1}\right)$, and their effect was also even.

Table 3. Leaf yield

\begin{tabular}{|c|c|c|c|}
\hline \multirow{3}{*}{ VARIANT } & \multicolumn{2}{|c|}{ YIELD $\left(\mathrm{t} \mathrm{ha}^{-1}\right)$} & \multirow{3}{*}{ AVERAGE } \\
\hline & \multicolumn{2}{|c|}{ Years } & \\
\hline & 1999. & 2000. & \\
\hline 1. $\mathrm{N}_{0} \mathrm{P}_{90} \mathrm{~K}_{80}$ & 38.67 & 42.86 & 40.76 \\
\hline 2. $\mathrm{N}_{80} \mathrm{P}_{90} \mathrm{~K}_{80}$ & 52.28 & 52.61 & 52.44 \\
\hline 3. $\mathrm{N}_{120} \mathrm{P}_{90} \mathrm{~K}_{80}$ & 69.61 & 62.14 & 65.87 \\
\hline 4. $\quad \mathrm{N}_{160} \mathrm{P}_{90} \mathrm{~K}_{80}$ & 71.78 & 61.26 & 66.52 \\
\hline $1-4$ & 58.08 & 54.72 & 56.40 \\
\hline AVERAGE & 64.56 & 58.67 & 61.61 \\
\hline $\begin{array}{ll}\text { LSD } & 0.05 \\
& 0.01\end{array}$ & $\begin{array}{c}7.18 \\
10.31\end{array}$ & $\begin{array}{c}7.42 \\
10.67\end{array}$ & $\begin{array}{l}- \\
-\end{array}$ \\
\hline
\end{tabular}

In similar traits with cauliflower, Everaarts (2000) obtained the yield increase of even $23.48 \mathrm{t} \mathrm{ha}^{-1}$. Alt et al. (2001) achieved the yield increase of $13.06 \mathrm{t} \mathrm{ha}^{-1}$. According to Kage et al. (2003), the highest cauliflower leaf yield $\left(56.11 \mathrm{~kg} \mathrm{ha}^{-1}\right)$ is obtained with the fertiliser rate of $220 \mathrm{~kg}$ nitrogen $\mathrm{ha}^{-1}$. According to Vasjanovic (1985) such yield is achieved with $140 \mathrm{~kg}$ nitrogen $\mathrm{ha}^{-1}$.

The total yield consists of the stem yield and the leaf yield. This yield amounted to $68.25 \mathrm{tha}^{-1}$ on the average and was higher by $4.51 \mathrm{t} \mathrm{ha}^{-1}$ in 1999 (Table 4). The response of cauliflower to nitrogen was positive and the fodder yield increase amounted to $26.20 \mathrm{t} \mathrm{ha}^{-1}$. The effects of nitrogen were higher in 1999 in which the yield increase amounted even to $32.83 \mathrm{t} \mathrm{ha}^{-1}$. The corresponding value in 2000 amounted to $19.57 \mathrm{t} \mathrm{ha}^{-1}$. Cauliflower did not respond more significantly to the increase of the nitrogen rate

Table 4. Total yield of fodder

\begin{tabular}{|c|c|c|c|}
\hline \multirow{3}{*}{ VARIANT } & \multicolumn{2}{|c|}{ YIELD $\left(\mathrm{t} \mathrm{ha}^{-1}\right)$} & \multirow{3}{*}{ AVERAGE } \\
\hline & \multicolumn{2}{|c|}{ Years } & \\
\hline & 1999. & 2000. & \\
\hline 1. $\mathrm{N}_{0} \mathrm{P}_{90} \mathrm{~K}_{80}$ & 45.88 & 51.32 & 48.60 \\
\hline 2. $\mathrm{N}_{80} \mathrm{P}_{90} \mathrm{~K}_{80}$ & 64.30 & 63.84 & 64.07 \\
\hline 3. $\quad \mathrm{N}_{120} \mathrm{P}_{90} \mathrm{~K}_{80}$ & 84.98 & 74.73 & 79.85 \\
\hline 4. $\quad \mathrm{N}_{160} \mathrm{P}_{90} \mathrm{~K}_{80}$ & 86.86 & 74.11 & 80.48 \\
\hline $1-4$ & 70.51 & 66.00 & 68.25 \\
\hline AVERAGE & 78.71 & 70.89 & 74.80 \\
\hline LSD & 6.55 & 7.21 & - \\
\hline 0.01 & 9.41 & 10.36 & - \\
\hline
\end{tabular}

from 120 to $160 \mathrm{~kg} \mathrm{ha}^{-1}$. Our results are completely in accordance with results obtained by Weich et al. (1985). These authors applied nitrogen in the amount ranging from 80 to $200 \mathrm{~kg} \mathrm{ha}^{-1}$ and obtained the yield increase of $17.34 \mathrm{t} \mathrm{ha}^{-1}$. Increasing nitrogen rates above $120 \mathrm{~kg} \mathrm{ha}^{-1}$ had no effects on cauliflower. Livingston et al. (1982) applied 100 and $150 \mathrm{~kg}$ nitrogen ha ${ }^{-1}$ and obtained the yield increase of 14.63 and $19.08 \mathrm{tha}^{-1}$, respectively. According to Vasjanovič (1985), the highest fodder yield is obtained with the application of 220 $\mathrm{kg}$ nitrogen $\mathrm{ha}^{-1}$. 


\title{
Conclusion
}

The average stem, i.e. leaf yield of cauliflower amounted to 11.85 , i.e. $56.40 \mathrm{tha}^{-1}$, respectively. The positive nitrogen effect is observable in the fodder yield increase of $26.20 \mathrm{t} \mathrm{ha}^{-1}$. The approximately even results were obtained in the trial variants with 120 and $160 \mathrm{~kg}$ nitrogen $\mathrm{ha}^{-1}$. Cauliflower yields were higher in the more favourable year (1999 with humid and warm weather). The fodder yield in 1999 was $70,51 \mathrm{t} \mathrm{ha}^{-1}$. It was observed that approximately $120 \mathrm{~kg}$ nitrogen ha ${ }^{-1}$ should be applied in the Belgrade region.

\section{UTICAJ KOLIČINE AZOTA NA PRINOS KRME U PROIZVODNJI KARFIOLA}

\author{
V. Bjelić, S. Vučković, Đ. Moravčević
}

\section{Rezime}

Karfiol je ispitivan u rejonu Beograda (Radmilovac). Ogledi su izvođeni dve godine (1999. i 2000). Tip zemljišta je gajnjača. Korišćena je sorta "siria". Varijante ogleda su: $\mathrm{N}_{0} \mathrm{P}_{90} \mathrm{~K}_{80}$ (kontrola), $\mathrm{N}_{80} \mathrm{P}_{90} \mathrm{~K}_{80}$ $\mathrm{N}_{120} \mathrm{P}_{90} \mathrm{~K}_{80}, \mathrm{~N}_{160} \mathrm{P}_{90} \mathrm{~K}_{80}$. Karfiol je stizao za berbu u oktobru (kasni karfiol).

Rezultati pokazuju prinos stabala, prinos lišća i ukupni prinos krme (stabla+lišće). Karfiol je u proseku donosio $68,25 \mathrm{t} \mathrm{ha}^{-1} \mathrm{krme}\left(11,85+56,40 \mathrm{tha}^{-1}\right)$. Azot je pozitivno uticao na karfiol, ali do određene granice. U stvari, taj uticaj je rastao od kontrole $\left(\mathrm{N}_{0}\right)$ do varijate sa $120 \mathrm{~kg} \mathrm{ha}^{-1}$ azota i onda se zaustavio. Tako se pokazalo da u ispitivanom području (rejon Beograda) za karfiol treba koristiti oko $120 \mathrm{~kg} \mathrm{ha}^{-1}$ azota.

\section{References}

9. ALT C., KAGE H., STUTZEL H. (2000): Optimal nitrogen content and photosynthesis in cauliflower (Brassica oleracea var. botrytis). Scaling up from a leaf to the whole plant. Annals of Botany, 85 (6), 779-787.

10. ALT C., KAGE H., STUTZEL H. (2001): Nitrogen status and light environment influence dry matter partitioning in cauliflower. Journal of the American Society for Horticultural Science, 126 (6), 750-756.

11. CSIZINSKY A.A. (1996): Optimum planting time, plant spacing, and nitrogen and potassium rates to maximize yield of green cauliflower. Hort Science, 31 (6), 930-933.

12. EVERAARTS A.P. (2000): Nitrogen balance during growth of cauliflower. Scientia Horticulturae, 83 (3/4), 173-186.

13. KAGE H., ALT C., STUTZEL H. (2003): Aspects of nitrogen use efficiency of cauliflower. Journal of Agricultural science, 141 (1), 1-16.

14. LIVINGSTON A.L., KNOVLES R.E., PAGE J., KUZMICKY D.D. (1982): Processing of cauliflower leaf waste for poultry and animal feed. Journal of Agricultural and Food Chemistry, 30 (2), 277-281.

15. MAKAREVIC A.J. (1998): Kapusta. Biblioteka sadovoda i ogorodnika, Slovo, Minsk, 87-93.

16. MANGAL J.L., PANDITA M.J., SINGH S.S. (1982): Effect of irrigation intensities and nitrogen levels on growth and yield of cauliflower (Brassica oleracea var. botryitis L.). Haryana Agriculture University Journal Research, 16 (3), 413-417.

17. VASJANOVIČ V.D. (1985): Vlijanije udobrenij i plošćadej pitania na urožaj cvetnoj kapusti. Sadovodstvo, 27 (4), 37-42.

18. WEICH N.C. TYLER K.B., RIRIE D., BROADBENT F.E. (1985): Nitrogen uptake by cauliflower. California Agriculture, 23 (12), 46-51. 